\title{
Memperkuat Kecakapan Siswa Melalui Werewolf in Education di SMAN 2 Blitar
}

\author{
Johan Edy Prastiwo
}

SMA Negeri 2 Blitar, Indonesia

Email: johanprastiwo77@gmail.com

\begin{tabular}{l}
\hline Tersedia Online di \\
\hline http://www.jurnal.unublitar.ac.id/ \\
index.php/briliant
\end{tabular}

\begin{tabular}{l}
\hline Sejarah Artikel \\
\hline Diterima pada 11 Februari 2020 \\
Disetujui pada 29 Februari 2020 \\
Dipublikasikan pada 29 Februari \\
2020 Hal. 137- 150
\end{tabular}

Kata Kunci:

Kecakapan siswa; Karakter;

Werewolf in Education

\begin{tabular}{l}
\hline DOI: \\
\hline http://dx.doi.org/10.28926/briliant \\
.v3i4.442 \\
\hline
\end{tabular}

\begin{abstract}
Abstrak: Tujuan dari pnelitian ini yaitu untuk memperkuat kecakapan siswa melalui permainan Werewolf in Education. Hasil kajian penulis tuangkan dalam makalah yang telah penulis uji cobakan dan telah penulis teliti melalui pendekatan kualitatif- analisis diskriptif. Sumber penulisan berasal dari eviden dilapangan dan pengalaman penulis yang terlibat langsung dalam permasalahan yang dibahas. Sasaran penulisan meliputi siswa, guru, komite hingga orang tua SMAN 2 Blitar. Setelah menggelar beberapa kali permainan Werewolf in Education dengan materi PPK, Adiwiyata, GLS, SKS dan Pendikel dengan melibatan Guru, Orang Tua dan pengurus Komite Sekolah sebagai unsur dari Tri Pusat Pembelajaran disimpulkan dapat memberikan penguatan Siswa berupa kecakapan, penguatan Karakter dan Literasi, mengembangkan wawasan dan menumbuhkan dukungan segenap warga seklah pada programprogram SMA Negeri 2 Blitar Tahun Pelajaran
\end{abstract}

2017/2018. Permainan Werewolf in Education disarankan terus digunakan sebagai salah satu pilihan dalam pembinaan Ekstrakurikuler, sebagai media sekolah dalam menjalin komunikasi dan mendapatkan dukungan orang tua dan pengurus kote sekolah. Penggunaan Werewolf in Education lebih lanjut sebagai model pembelajaran didalam kelas dengan modifikasi materi game yang sesuai dengan Kompetensi Dasar (KD) pada masing-masing mata pelajaran.

\section{PENDAHULUAN}

Pandangan di masyarakat dan praktisi pendidikan menganggap bahwa indikator keberhasilan pembelajaran sebagai inti proses pendidikan adalah nilai Ujian Nasional, pandangan seperti itu tidak sepenuhnya keliru, akan tetapi sudut pandang tersebut kurang multidimensional, apabila keberhasilan hanya dilihat dari satu dimensi saja maka pendidikan hanya dilihat dari segi kognitif saja, sedangkan aspek yang lain terdapat tendensi diabaikan.

Kecakapan hidup sebagai inti dari kompetensi dan hasil pendidikan adalah kecakapan yang dimiliki seseorang untuk berani menghadapi problema hidup dan kehidupan yanh wajar tanpa merasa tertekan, kemudian secara proaktif dan kreatif menemukan solusi sehingga akhirnya mampu mengatasi, inilah yang dimaksud dengan kecakapan yakni bukan lagi akademik saja namun manajemen hidup termasuk didalammnya manajemen konflik dan manajemen stress, sebagai hasil dari pendidikan pembelajaran yang mengarah dalam kecakapan hidup prinsip utamanya adalah adanya proses keterlibatan seluruh atau sebagian besar potensi diri siswa (fisik dan non fisik) dan kebermaknaannya bagi diri dan di masa yang 
akan datang. Sedangkan latar belakang diterapkannya konsep pendidikan berorientasi kecakapan hidup di antaranya karena tantangan globalisasi yang menuntut kualitas sumber daya manusia yang prima dan unggul dalam persaingan di pasar global

Penguatan pendidikan karakter, literasi dan kecakapan 4C di SMA Negeri 2 Blitar melalui tiga jalur yaitu 1) Pembelajaran di kelas, 2) kegiatan siswa pada ekstrakurikuler dan 3) program sekolah Adiwiyata, Sistem Kredit Semester (SKS), Gerakan Literasi Sekolah (GLS) dan Pendidikan Keluarga (implementasi Tri Pusat Belajar dalam optimalisasi paguyuban orang tua setiap kelas). Kurang pemahaman dan penghayatan karena kurang keterlibatan secara langsung unsurunsur pendukung Tri Pusat Belajar (sekolah, keluarga dan masyarakat) dalam pengembangan diri siswa dan program-program sekolah. Pada jalur ke-2 dan ke-3 tersebut membutuhkan pemilihan model pembelajaran untuk internalisasi program sebagai variasi model supaya lebih menarik, kontekstual, kekinian dan partisipatif/menyeluruh.

Werewolf game sebagai permainan kelompok-kelompok anak muda yang lagi popular berpotensi mengembangkan kecakapan berfikir kritis, berkomunikasi, berkolaborasi dan berkreasi, serta mampu membangun karakter kepemimpinan dan integritas, berpeluang sebagai model yang tepat bagi sekolah dalam pengembangan diri siswa dan internalisasi program sekolah. Dengan melibakan siswa dengan unsurunsur Tri Pusat Belajar yaitu guru/sekolah, orang tua/keluarga dan komite sekolah/ masyarakat dalam Werewolf in Education dengan alternatif materi PPK Adiwiyata, Gerakan Literasi Sekolah (GLS), Sistem Kredit Semester (SKS) dan Pendidikan Keluarga (Pendikel) pada forum Ekstrakurikuler diharapkan mampu menumbuhkan kecakapan berfikir kritis, berkomunikasi, berkolaborasi dan berkreasi (4C) serta lebih menghayati, mendukung dan mengambil peran dalam pelaksanaan program-program

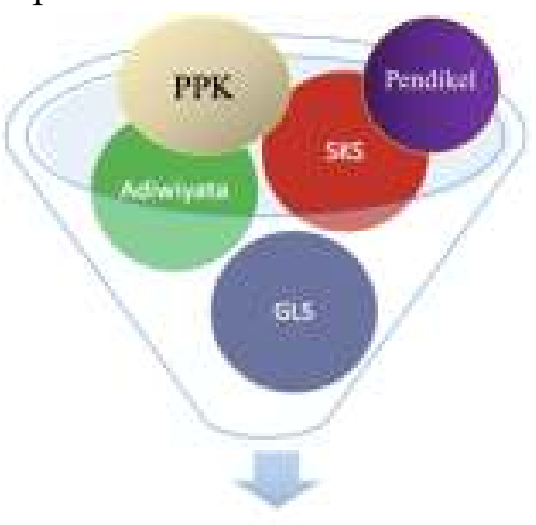

4C-Literasi-Berkarakter

Gb. 1.1 Materi dan target Werewolf in Education sekolah. Untuk mencapai tujuan tersebut penulis menyusun makalah hasil kajian ini dengan judul "Memperkuat kecakapa Siswa melalui Werewolf in Education di SMAN 2 Blitar Tahun Pelajaran 2017/2018".

Dari latar belakang diatas, permasalahan yang akan dibahas oleh penulis adalah Bagaimanakah meningkatkan kecakapan hidup, Literasi dan Karakter siswa melalui Werewolf in Education dengan materi Penguatan Pendidikan Karakter (PPK) Adiwiyata, GLS, SKS dan Pendikel dengan melibatkan peran unsur Tri Pusat Belajar dalam Ekstrakurikuler SMA Negeri 2 Blitar Tahun Pelajaran 2017/2018?. Adapun tujuan dari penulisan makalah ini untuk meningkatkan kecakapan hidup), Literasi dan Karakter siswa melalui Werewolf in Education materi Penguatan Program Sekolah Pendidikan Karakter Adiwiyata, GLS, SKS dan Pendikel dengan melibatkan peran unsur Tri Pusat Belajar dalam Ekstrakurikuler SMA Negeri 2 Blitar Tahun Pelajaran 2017/2018. Manfaat yang akan diharapkan setelah menyelesaikan tulisan ini antara lain: 1) Secara Teoritis untuk menambah kajian keilmuan bidang pendidikan dan pembelajaran tingkat Sekolah Menengah Atas khususnya SMAN 2 Blitar, dapat memahami polemik atau suatu peristiwa/ masalah di kalangan civitas pendidikan dan membantu 
mencarikan solusi alternatif permasalahannya, untuk membangun teori pengetahuan dalam rangka memverifikasi teori atau menemukan teori baru, memberikan gambaran riil dilapangan mengenai pemecahan masalah dibidang pendidikan yang memiliki nilai kajian tinggi dengan berbagai permasalahan yang terjadi di dalamnya. 2) Secara Praktis; untuk Siswa dan Guru dapat memperkuat kecakapan hidup siswa), Literasi dan Karakter, semakin memahami program sekolah dalam pengembangan Penguatan Pendidikan Karakter, Adiwiyata, Gerakan Literasi Sekolah dan Sistem Kredit Semester (SKS), menambah keterampilan belajar siswa dan model pembelajaran/pelatihan guru khususnya model Werewolf in Education dalam kegiatan ekstrakurikuler.

\section{A. Werewolf Game}

Permainan dengan jumlah pemain umumnya antara 6 orang hingga 20 orang yang terdiri dari dua kelompok yang berseteru yaitu kelompok baik memerankan kelompok warga desa dengan kelompok jahat yang memerankan satu atau beberapa werewolf (jika pemainnya terbatas hanya seorang werewolf), dipimpin oleh seorang moderator sekaligus bertindak sebagai narrator. Dalam permainannya ini setiap kelompok saling serang pada wilayah waktunya masingmasing. Kelompok jahat menyerang saat fase malam hari, dan kelompok baik berburu dan menangkapnya pada siang hari. Pada setiap siklus yang terdiri dari dua fase yaitu malam dan siang itu terulang beebrapa kali hingga berakhir saat salah satu kelompok berhasil ditumpas dan kelompok lainnya dapat bertahan hidup. Werewolf Game memiliki berbagai varian pengembangan dengan berbagai varian peran.

Kartu peran pemain, pada permainan berikut memilih varian yang paling sederhana dengan jumlah pemain 9 orang masing-masing berperan sebagai berikut; seorang moderator sekaligus sebagai narrator, dua orang peran jahat sebagai werewolf, peran baik seorang Seer (penyihir), peran Guardian (pelindung), dan empat orang pemain peran baik sebagai Villager (penduduk desa).

\section{Langkah-langkah Warewolf Game}

A. Pendahuluan

1. Moderator menyampaikan aturan dan urutan permainan.

2. Moderator membagi kartu pemain.

B. Waktu/ fase malam hari sebagai fase Warewolf membunuh warga

1. Moderator meminta semua pemain "tidur" (berpura-pura tidur dengan cara memejamkan mata dan menunduk).

2. Moderator meminta sesaat pada Werewolf unjuk diri dengan cara tengadah dan membuka mata, selanjutnya Werewolf memilih 1 pemain untuk dieksekusi. Setelah moderator mencatat sasaran Werewolf, meminta pada werewolf untuk "tidur".

3. Moderator meminta Guardian (pelindung) memilih satu pemain yang akan dilindunginya dengan isyarat menunjuk 1 orang yang dilindunginya, yang diduga sebagai sasaran werewolf, moderator mencatatnya

4. Moderator meminta Seer (penyihir) unjuk diri, dan menanyakan padanya mana yang ingin diterawang (scan) status 1 (satu) orang pemain yang diduga sebagai werewolf. 
5. Moderator memberi isyarat dengan tiga jari/W (jika yang ditunjuk ternyata werewolf) atau dengan memberi isyarat dua jari/V (jika yang ditunjuk ternyata Villager)

\section{METODE}

Metode Penelitian pada makalah ini adalah melalui pendekatan kualitatifanalisis diskriptif. Sumber penulisan berasal dari eviden dilapangan dan pengalaman penulis yang terlibat langsung dalam permasalahan yang dibahas. Sasaran penulisan meliputi siswa, guru, komite hingga orang tua/wali murid SMAN 2 Blitar. Adapun tahapan pada penulisan makalah ini adalah: 1) Tahap pra-lapangan yaitu bertujuan memperoleh gambaran yang lengkap dan jelas mengenai lokasi dan keadaan objek penulisan, gambaran umum sumber penulisan, arah dan rumusan masalah yang ditulis, penyesuaian waktu dan lain-lain yang berhubungan dengan penulisan. Pada tahap ini secara umum dilakukan kegiatankegiatan meliputi; (1) Memilih topik, dengan pertimbangan bahwa permainan edukasi werewolf saat ini menjadi trend dikalangan siswa dan generasi muda sehingga akan lebih antusias jika dimodifikasi dengan muatan- muatan pendidikan Adiwiyata, literasi, PPK bahkan sangat diharapkan mendukung penguatan kecakapan abad 21 4C; (2) Mengurus pengkomukasian/ melakukan sosialisasi, baik secara informal ke pihak warga SMAN 2 Blitar, maupun secara formal ke pihak komite, wali murid maupun stakeholder yang terlibat; (3) Melakukan penjajakan lapangan dan lingkungan obyek penulisan, dalam rangka penyesuaian dengan atmosfer pembelajaran dan situasi SMAN 2 Blitar sebagai obyek penulisan. 2) Tahap pekerjaan lapangan

Adapun sumber primer lisan diperoleh melalui testimoni dengan orangorang yang berkompeten dalam peristiwa. Testimoni yang dilakukan dengan para partisipan (guru, Kepala Sekolah, Komite, Siswa, Wali Murid) dapat dibedakan ke dalam tiga ketegori, yaitu: orang-orang yang terlibat langsung, orang-orang yang menyaksikan atau mengamati tetapi tidak terlibat langsung, dan orang-orang yang tidak terlibat langsung tetapi mendapat keterangan dari orang yang terlibat kemudian ikut menjadi partisipan sebagai dampaknya. Data primer adalah data yang langsung dikumpulkan oleh penulis (atau petugas-petugasnya) dari sumber pertama. 2) Sumber sekunder,data sekunder diperoleh dari artikel-artikel dan laporan penelitian dari peneliti lain yang berhubungan dengan penelitian ini, yang sudah bersifat jamak diperoleh dari perpustakaan dan badan arsip yang mempunyai relevansi untuk memperkuat argumentasi dan melengkapi hasil penulisan. Dalam penelitian ini penulis menggunakan tiga macam teknik pengumpulan data, yaitu: Observasi atau Pengamatan, Interview (Wawancara/Testimoni/ Tanggapan) dan dokumentasi.

\section{HASIL}

Sebagai dasar pemilihan media dalam penguatan abad 21 dan wahana internalisasi program-program sekolah perlu dipastikan efektifitas Werewolf Game. Werewolf Game dengan berbagai variannya umumnya telah memiliki beberapa kelebihan disamping beberapa kelemahan. Dengan mencermati, menganalisis dan mengevaluasi Werewolf Game pada bahasan Bab II Sub Bab

140 BRILIANT: Jurnal Riset dan Konseptual Volume 5 Nomor 1, Februari 2020 
A.1 tersebut, keunggulan atau keuntungan dan kelemahan atau efek samping Werewolf Game disajikan pada Tabel 4.1

Tabel 4.1 Analisa keunggulan dan kekurangan Werewolf Game

\begin{tabular}{cll}
\hline NO & KEUNGGULAN/ KEUNTUNGAN & KEKURANGAN/ DAMPAK \\
\hline 1 & $\begin{array}{l}\text { Dapat digunakan dalam berlatih berfikir } \\
\text { kritis, berkomunikasi, berkolaborasi, } \\
\text { berkreasi dalam strategi bermain peran. }\end{array}$ & $\begin{array}{l}\text { Karena tidak fokus dalam batasan materinya, } \\
\text { maka jalannya diskusi dalam bermain peran } \\
\text { kurang terarah. }\end{array}$ \\
2 & $\begin{array}{l}\text { Bersifat menantang, melibatkan } \\
\text { pengendalian emosi dan menarik. }\end{array}$ & $\begin{array}{l}\text { Kurang efektif dalam penggunaan waktu } \\
\text { belajar, mengingat dalam kurum waktu } \\
\text { permainan, pemain kurang mendapatkan } \\
\text { wawasan materi. }\end{array}$ \\
& $\begin{array}{l}\text { Mudah mendapatkan kartu permainan } \\
\text { karena dijual di pasaran. }\end{array}$ & $\begin{array}{l}\text { Umumna terbatas pada kumunitas anak } \\
\text { muda. }\end{array}$ \\
\hline
\end{tabular}

\section{PEMBAHASAN}

A. Werewolf in Education sebagai Media Pemecahan Masalah

Werewolf in Education adalah sebuah permainan yang dikembangkan dari Werewolf Game varian dasar. Jika pada Werewolf Game semata-mata hebohnya pada perburuan werewolf berdasar gerak gerik pemain dengan menggunakan argument kepentingan kemenangan dalam game tanpa ada muatan wawasan, berbeda dengan Werewolf in Education hebohnya permainan untuk memenangkannya perlu alasan logis berdasarkan penguasaan materi dari kartu yang diperankan maupun materi kartu yang diperankan lawannya. Werewolf in Education diperkaya materi PPK, Adiwiyata, GLS, SKS dan program Tri Centra Pendidikan atau Tri Pusat Belajar.

1. Pengembangan Peran

a. Heteroginitas Pemain

Pada werewolf game pemain umumnya homogin, terbatas pada kalangan muda saja, sehingga tidak sempat memahami pola pemikiran dengan adanya perbedaan usia pemain maupun latar belakang kepentingannya. Sedang pada permainan Werewolf in Education pemain dibuat heterogen, berasal dari berbagai unsur Tripusat Belajar dengan target ketercapaian adalah siswa. Heterogenitas pemain dari unsur Tripusat Pembelajaran seperti pada Tabel 4.2

Tabel 4.2 Unsur Pemain dari Tri Pusat Pembelajaran

\begin{tabular}{cllc} 
NO & \multicolumn{1}{c}{ PEMAIN } & $\begin{array}{c}\text { UNSUR TRIPUSAT } \\
\text { BELAJARAN }\end{array}$ & $\begin{array}{c}\text { JUMLAH } \\
\text { PEMAIN PER } \\
\text { KELOMPOK }\end{array}$ \\
\hline 1 & $\begin{array}{l}\text { Siswa peserta ekstra } \\
\text { kurikuler }\end{array}$ & Subyek permainan & 5 orang \\
& Guru & Sekolah & 1 orang \\
3 & Orang tua & Keluarga & 2 orang \\
4 & Pengurus komite & Masyarakat & 1 orang \\
\hline & \multicolumn{2}{c}{ Jumlah pemain setiap kelompok } & $\mathbf{9}$ orang \\
\hline
\end{tabular}

b. Pengembangan Peran dari berbagai Unsur Warga Sekolah 
Peran pada Werewolf in Education berkembang dengan nama peran yang layaknya ada pada sekolah antara lain warga sekolah (mewakili siswa, guru, tenaga administrasi, pengurus komite, orang tua sisiwa), ketua OSIS, dan Guru BK dan Moderator/Narrator/KS (Kepala Sekolah). Sedangkan peran yang berasal dari luar lingkungan sekolah antara lain peran Tokoh Spiritual dan Perusuh/Werewolf. Semua peran tersebut semuanya dapat dimainkan secara acak oleh siswa, guru, orang tua siswa maupun pengurus komite sekolah. Jika dibandingkan dengan permainan asalnya pada Werewolf Game pada Werewolf in Education banyak peran pengembangan, sehingga lebih kontekstual.

Tabel 4.3 Pengembangan Peran pada Werewolf in Education

\begin{tabular}{rlcclc}
\hline NO & $\begin{array}{c}\text { Peran Pengembangan } \\
\text { Werewolf in Education }\end{array}$ & $\begin{array}{c}\text { Jumlah } \\
\text { Pemain } \\
\text { org }\end{array}$ & $\begin{array}{c}\text { Status } \\
\text { tokoh }\end{array}$ & $\begin{array}{c}\text { Peran Asal } \\
\text { pada Werewolf } \\
\text { Game }\end{array}$ & Keterangan \\
\hline 1 & Moderator/Narator/KS & 1 org & Netral & $\begin{array}{l}\text { Moderator/ } \\
\text { Narator }\end{array}$ & tetap \\
2 & Warga Sekolah & 3 org & V/baik & Villager & dikembangkan \\
3 & Ketua Osis & 1 org & V/baik & Walikota & dikembangkan \\
4 & Guru Bimbingan Karir/ & 1 org & V/baik & Guardian & dikembangkan \\
& BK & 1 org & W/baik & Seer & dikembangkan \\
5 & Tokoh Spiritual & 2 org & W/jahat & Werewolf & dikembangkan \\
\hline 6 & Perusuh & & & & \\
\hline
\end{tabular}

Keterangan:

$\mathrm{V}$ : Villager peran internal sekolah diisyaratkan dengan dua jari

W: Tokoh dari luar sekolah diisyaratkan dengan tiga jari

10 Muatan Materi pada Kartu Pemain

Muatan materi tertuang dalam kartu game hal ini di implementasikan pada jenis kartu yang digunakan dan termasuk dalam pengembangan yang sengaja dilakukan penulis agar tujuan penulisan karya tulis ilmiah ini dapat tercapai dan lebih memiliki nilai edukatif/ pendidikan yang lebih dibanding dengan permainan werewolf dengan versi asli.

Dalam bermain peran pada permainan Werewolf in Education setiap pemain mendapatkan kartu pemain. Diskripsi didalam kartu memberi gambaran peran yang harus dimainkan oleh masing-masing pemain. Sosok kartu beserta isinya selain menggambarkan jalannya permainan juga berisi sub tema materi yang harus dikuasai masing-masing pemain. Berikut contoh salah satu jenis kelompok kartu, misalnya kelompok kartu PPK. Warga sekolah sebagai pemain mendapat 1 buah kartu dari 9 buah kartu dengan indentitas masing masing 1) Moderator/narator berisi arahan peran, tanpa berisi materi; 2) Warga Sekolah materi Relegius; 3) Warga Sekolah materi Nasionalis; 4) Warga Sekolah materi Mandiri; 5) Warga Sekolah materi Gotongroyong; 6) Guru BK/Guardian/Pelindung Sekolah materi Integritas; 7) Tokoh Spiritual/Seer berisi arahan peran, tanpa materi; 8) Perusuh/ Werewolf, berisi arahan peran, tanpa berisi materi; 9) Perusuh/ Werewolf, berisi arahan peran, tanpa berisi materi.

a) Moderator/Narrator 


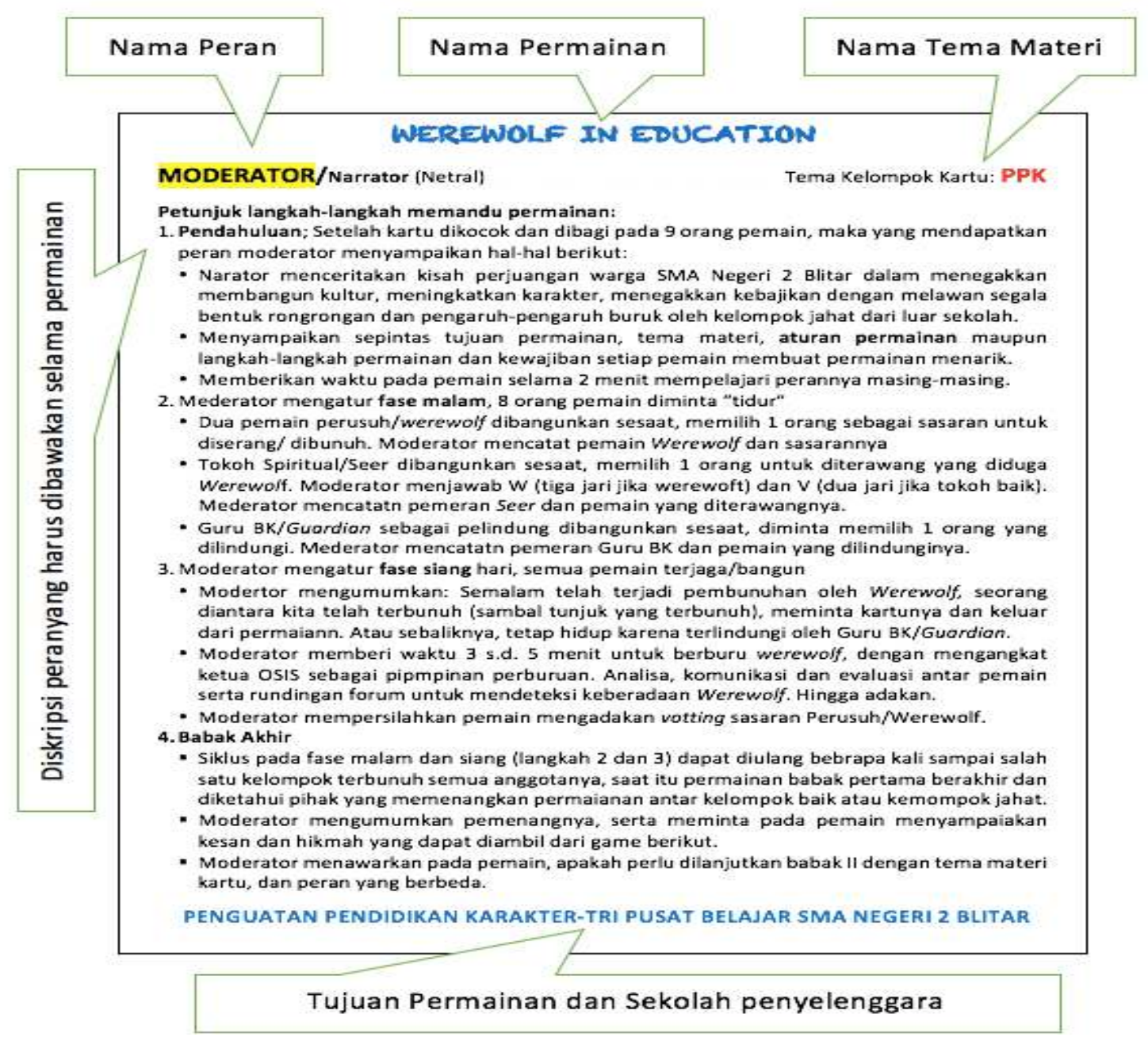

\section{Gb. 4.1 Kartu Moderator}

Kartu Moderator dimainkan oleh satu orang. Kartu ini berisi arahan peran, tanpa berisi materi, berisi arahan singkat tentang memandu permaianan dan suasana yang harus dikondisikan selama permainan supaya permainan lancar, menarik, hingga mampu membuat pemain hidup dan bersemangat dalam mendukung keberhasilam permainan

\section{b) Warga Sekolah Umumnya/Villager}

Ada 5 orang pemain yang memerankan warga baik internal sekolah (V) yang terdiri dari 4 orang warga sekolah umumnya tanpa memiliki kekuatan tambahan dan 1 orang pemain warga sekolah dengan kekuatan tambahan sebagai pelindung/guardian yaitu Guru BK. Kelima pemain itu memiliki kartu yang berisi saran yang harus dibawakan dan materi yang harus dikuasai sebagai peran ahli dalam bagian tema materi game, misalnya untuk kelompok kartu materi PPK 4 buah kartu masing-masing adalah Warga Sekolah materi Relegius, Warga Sekolah materi Nasionalis, Warga Sekolah materi Mandiri, Warga Sekolah materi Gotong Royong 


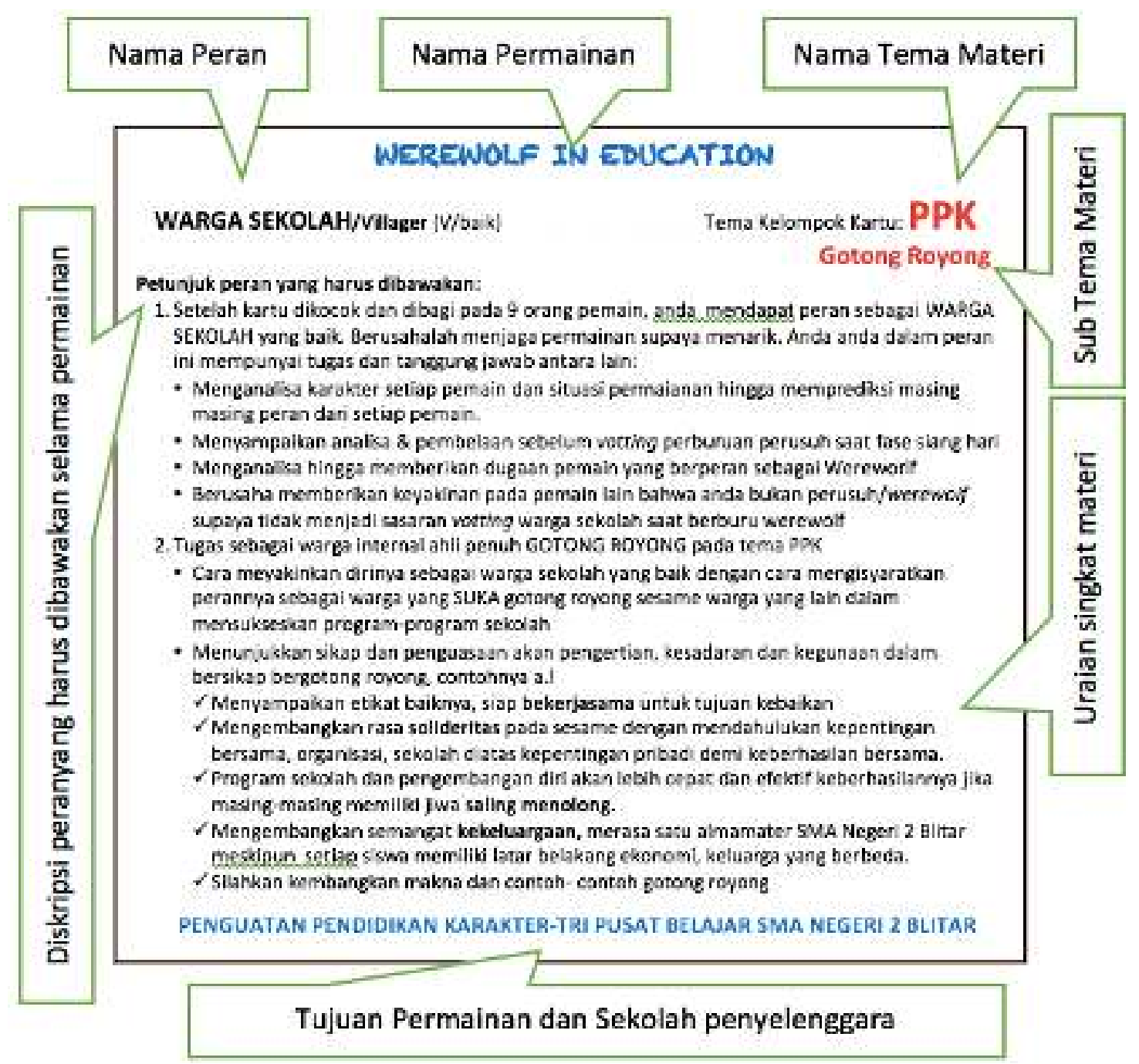

c) Guru BK/Pelindung Warga Sekolah/Guardian

Gb. 4.2 Kartu Warga Sekolah

Diantara 5 orang pemain yang memerankan warga baik internal sekolah (V) 1 orang pemain warga sekolah dengan kekuatan tambahan sebagai pelindung/guardian yaitu Guru BK memiliki kartu seperti halnya 4 kartu warga baik internal lainnya, tetapi juga berisi diskripsi strategi dan tugas khusus yang harus dibawakan, Jenis kartu ini membuat peran pemain yang membawakannya menjadi penting karena memiliki kekuatan yang dapat menggagalkan serangan Perusuh/Werewolf pada warga baik saat fase malam hari, sekaligus pemain pembawa kartu ini karena kelebihan kekuatannya umumnya menjadi sasaran utama

Perusuh/Werewolf. Gambar 4.3 adalah contoh kartu Guru BK/ Pelindung Warga Sekolah/Guardian. 


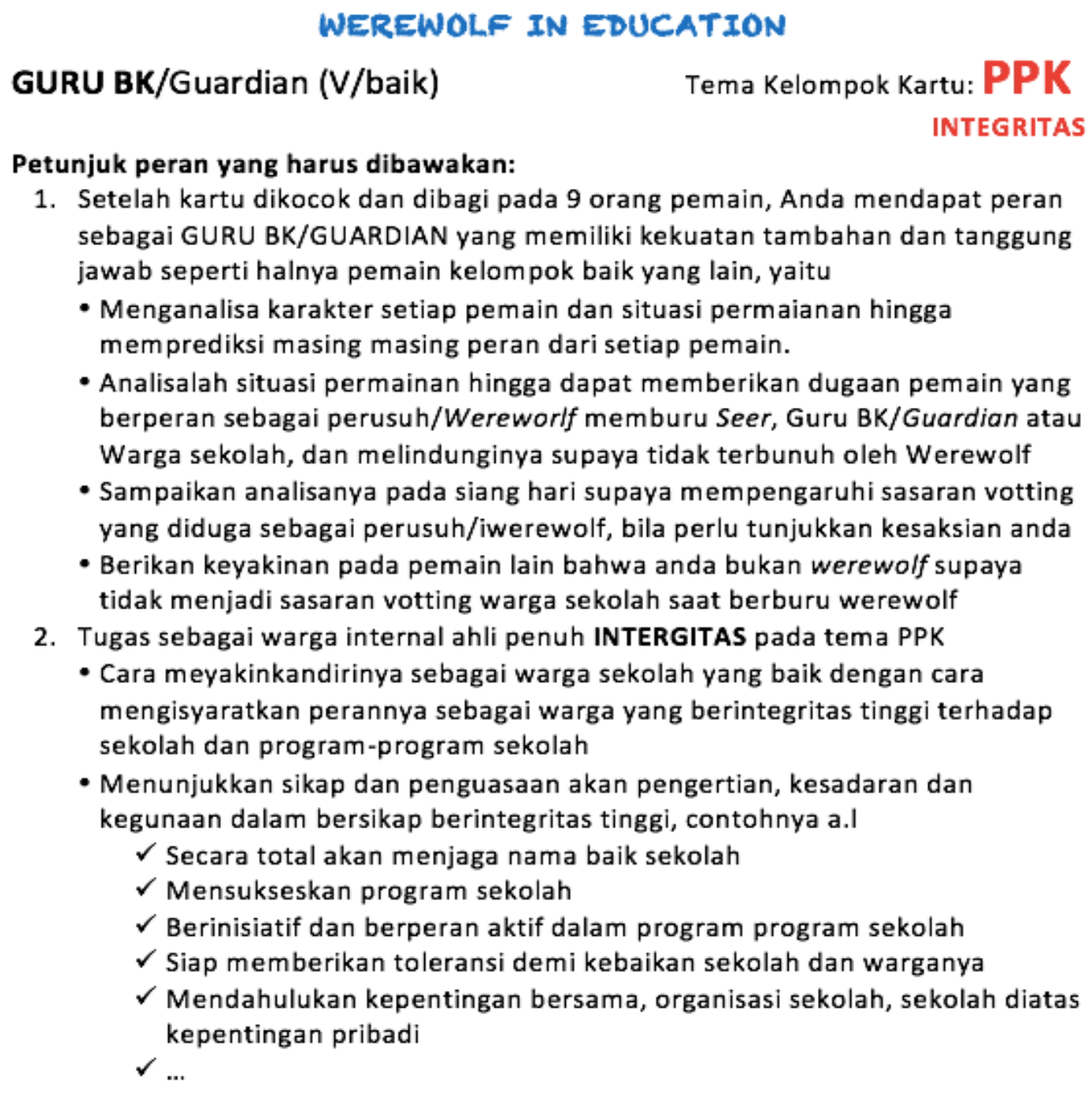

1. Setelah kartu dikocok dan dibagi pada 9 orang pemain, Anda mendapat peran sebagai GURU BK/GUARDIAN yang memiliki kekuatan tambahan dan tanggung jawab seperti halnya pemain kelompok baik yang lain, yaitu

- Menganalisa karakter setiap pemain dan situasi permaianan hingga memprediksi masing masing peran dari setiap pemain.

- Analisalah situasi permainan hingga dapat memberikan dugaan pemain yang berperan sebagai perusuh/Wereworlf memburu Seer, Guru BK/Guardian atau Warga sekolah, dan melindunginya supaya tidak terbunuh oleh Werewolf

- Sampaikan analisanya pada siang hari supaya mempengaruhi sasaran votting yang diduga sebagai perusuh/iwerewolf, bila perlu tunjukkan kesaksian anda

- Berikan keyakinan pada pemain lain bahwa anda bukan werewolf supaya tidak menjadi sasaran votting warga sekolah saat berburu werewolf

2. Tugas sebagai warga internal ahli penuh INTERGITAS pada tema PPK

- Cara meyakinkandirinya sebagai warga sekolah yang baik dengan cara mengisyaratkan perannya sebagai warga yang berintegritas tinggi terhadap sekolah dan program-program sekolah

- Menunjukkan sikap dan penguasaan akan pengertian, kesadaran dan kegunaan dalam bersikap berintegritas tinggi, contohnya a.l

$\checkmark$ Secara total akan menjaga nama baik sekolah

$\checkmark$ Mensukseskan program sekolah

$\checkmark$ Berinisiatif dan berperan aktif dalam program program sekolah

$\checkmark$ Siap memberikan toleransi demi kebaikan sekolah dan warganya

$\checkmark$ Mendahulukan kepentingan bersama, organisasi sekolah, sekolah diatas kepentingan pribadi

PENGUATAN PENDIDIKAN KARAKTER-TRI PUSAT BELAJAR SMA NEGERI 2 BLITAR

d) Tokoh Spiritual/Seer

Gb. 4.3 Kartu Guru BK/Pelindung/Guardian

Kartu peran Spiritual/Seer ini menggambarkan tokoh yang memiliki kekuatan lebih dalam menerawang pemain lain termasuk Perusuh/Werewolf, tokoh yang berasal dari luar lingkungan sekolah tetapi memiliki etikat baik dalam mendukung program sekolah dan dalam perburuan Perusuh/Werewolf sangat berperan. Saat warga sekolah lainnya meragukan indentitas seseorang yang diduga Perusuh/Werewolf tokoh ini terkadang mampu mengklarifikasinya berdasarkan kemampuan menerawang pada malam sebelumnya. Sebaliknya tokoh ini cenderung dicurigai oleh warga sekolah karena tidak mendapatkan informasi program-program sekolah pada kartunya. Tokoh pemegang kartu ini juga sebagai sasaran utama Perusuh/Werewolf. Sungguh tantangan yang menariksaat memerankan tokoh Spiritual/Seer ini. Pada Gambar 4.4 menunjukkan sosok dan misi dari kartu tokoh Spiritual/Seer. 


\section{WEREWOLF IN EDUCATION \\ TOKOH SPIRITUAL/Seer (W/baik) \\ Tema Kelompok Kartu: PPK}

Petunjuk peran yang harus dibawakan:

1. Setelah kartu dikocok dan dibagi pada 9 orane pemain, maka yane mendapatkan peran TOKOH RELEGIUS/SEER. Tokoh ini dari luar sekolah (W), tetapi mendukung sekolah ( $V$ ) dengan memanfaatkan kelebihan spiritualnya. Tokohini memiliki tanggung jawab tambahan:

- Menganalisa karakter setiap pemain dan situasi permaianan hingga memprediksi masing masing peran dari setiap pemain.

- Menganalisa keberadaan werewoif untuk diterawang pada malam hari

- Pada siang hari ikut menganalisa dalam berburu werewolf hingga memberikan berpeluang menang pada pihak warga sekolah.

- Memberikan keyakinan pada pemain lain bahwa dirinya bukan werewolf supaya tidak menjadi sasaran votting warga sekolah saat berburu werewolf.

2. Tugas dan strategi sebagai kelompok baik dan ahli.

- Cara meyakinkan bahwa dirinya berpihak pada kelompok baik yaitu pihak warga sekolah dalam melawan/berburu werewolf.

- Menunjukkan sikap dan penguasaan akan pengertian, kesadaran dan kegunaan dalam tema PPK secara umum meskipun tidak ada panduan rinci dalam kartu, contohkan dengan baik sub tema PPK Relegius, Nasionalis, Mandiri, Integritas, dan Gotong Royong.

- Kesempatan anda dalam berlatih kecakapan 4ici lebih menantang dari pada peran yang lain, maka berusahalah. Ambil kesempatan ini dan jaga permainan menjadi menarlk.

PENGUATAN PENDIDIKAN KARAKTER-TRI PUSAT BELAJAR SMA NEGERI 2 BLITAR

e) Perusuh/ Werewolf,

Gb. 4.4 Kartu tokoh Spiritual/Seer.

Tokoh werewolf sebagai peran utama yang sangat menantang, paaling berpeluang mengasah kecakapan dalam berfikir kritis, berkomunikasi, berkolaborasi dan berkreasi (4C). pada kartunya tidak didiskripsikan materi. Tetapi tokoh ini harus pintar dan dituntut menguasai materi sesuai tema dan program-program sekolah supaya dapat memperdaya pemain lainnya karena dianggap sebagai tokoh kelompok warga sekolah yag baik. Berikut pembagian pemain peran sekaligus sebagai nama kartu dalam permaianan Werewolf in Education. Pada setiap jenis kelompok kartu masing masing sebagai berikut:

146 BRILIANT: Jurnal Riset dan Konseptual Volume 5 Nomor 1, Februari 2020 


\section{WEREWOLF IN EDUCATION}

\section{PERUSUH/Werewolf (W)}

\section{Tema Kelompok Kartu: PPK}

\section{Petunjuk Peran yang harus dibawakan:}

1. Setelah kartu dikocok dan dibagi pada 9 orang pemain, Anda mendapat peran SEDagal PERUSUH/WEREWOLF.

- Tokoh darl luar sekolah yane menyamar sebagal warga sckolah yane balk.

- Anda berperan sebagai tokoh antagonis/jahat mengujl tokoh lain dengan memerankan sebaik mungkin sebagai salah satu dari peran baik.

- analisalah karakter setiap pemain dan situasi permaianan hingga menentukan sasaran yang akan anda bunuh pada saat malam hari.

- Dalam menentukan sasaran perburuan perlu kesepakatan dengan pasangan Anda sesame Werewolf.

- Anda dapat memilih tokoh-tokoh kuat terlebih dulu sebagai sasaran karena tokoh ini sangat menghalangi misi Perusuh/Werewolf, misalnya Guru BK/Pelindung/Guardian atau Tokoh Spiritual/Seer atau ketua OSIS, atau justru warga awam sekolah yang umumnya tidak terlindng oleh Guardian, hinega semua tokoh baik terbunuh, baik pada malam maupun siang hari.

- Berikan keyakinan pada pemain lain bahwa diri Anda bukan Werewolf supaya tidak menjadi sasaran votting warga sekolah saat berburu werewolf.

2. Strategi sebagai kelompok jahat yang berpura pura baik

- Yakinkan Anda menguasai materi sesuai dengan tema kartu

- Tokoh werewolf sebagal peran utama yang sangat menantang, paaling berpeluang mengasah kecakapan dalam berflkir kritis, berkomunikasi, berkolaborasi dan berkreasi (4C).

- Pastikan anda menguasai program-program sekolah

- Semuanya hanyalah permaianan, ikutlah andil sebaik mungkin hingga permainan menarik.

\section{Gb. 4.5 Kartu Perusuh/Werewolf}

Demikianlah isi kartu-kartu dari tema materi PPK, sebagai salah satu tema kartu. Untuk jenis kelompok kartu materi lainnya berisi arahan peran yang sejenis dengan materi yang berbeda sesuai dengan temanya masing-masing. Berikut adalah diskripsi singkat tentang sub tema materi pada setiap tema.

Diskripsi umumnya pada kartu ditulis singkat dengan harapan setiap pemain dapat mengembangkan wawasannya sesuai dengan kata kunci/diskripsi singkat pada kartu untuk memberikan peluang berfikir kritis, berkomunikasi, berkolaborasi dan berkreasi saat berdiskusi perburuan perusuh/werewolf. Sedangkan untuk materi baru diberikan tambahan diskripsi pada sub tema materinya supaya diskusi berjalan hidup.

\section{Kelompok Kartu Werewolf in Education}

a. Kelompok Kartu PPK (Penguatan Pendidikan Karakter)

Kartu kelompok ini mendalami PPK khususnya aspek relegius, naionalis, mandiri, gotong royong dan integritas. Kartu kelompok ini memiliki 9 jenis kartu masing-masing sebagai berikut; (1) Moderator/Narator, (2) Warga Sekolah Relegius, (3) Warga Sekolah Nasionalis, (4) Warga Sekolah Mandiri, (5) Warga 
Sekolah Gotong royong, (6) Pelindung Warga Sekolah Integritas, (7) Tokoh Spiritual/Seer, (8) Perusuh/ Werewolf, (9) Perusuh/ Werewolf

\section{b. Kelompok Kartu Adiwiyata}

Kartu kelompok ini mendalami Adiwiyata khususnya aspek pengertian dan tujuan adiwiyata, partisipasi dan kemitraan adiwiyata, prinsip adiwiyata, obyek lingkungan dan isyu lingkungan, dan jenjang adiwiyata. Kartu kelompok ini memiliki jenis 9 kartu masing-masing adalah sebagai berikut; (1) Moderator/Narator, (2) Guru BK/Pelindung Warga Sekolah Pengertian dan Tujuan Adiwiyata, (3) Warga Sekolah Partisipatif dan Kemitraan Adiwiyata, (4) Warga Sekolah Prinsip Adiwiyata, (5) Warga Sekolah Obyek Lingkungan dan Isu Lingkungan, (6) Warga Sekolah Jenjang Adiwiyata, (7) Tokoh Spiritual/Seer, (8) Perusuh/ Werewolf, (9) Perusuh/ Werewolf

\section{c. Kelompok Kartu GLS (Gerakan Literasi Sekolah)}

Kartu kelompok ini mendalami Gerakan Literasi Sekolah (GLS) khususnya aspek Pengertian Literasi dan GLS, Komponen Literasi, Tahapan GLS, Tujuan GLS, Contoh Gerakan Literasi. Sekolah Kartu kelompok ini memiliki 9 jenis kartu masing-masing adalah sebagai berikut; (1) Moderator/Narator, (2) Pelindung Warga Sekolah Pengertian Literasi dan GLS, (3) Warga Sekolah Tujuan GLS, (4) Warga Sekolah Komponen Literasi, (5) Warga Sekolah Tahapan GLS, (6) Warga Sekolah Contoh GLS di SMA Negeri 2 Blitar, (7) Tokoh Spiritual/Seer, (8) Perusuh/ Werewolf, (9) Perusuh/ Werewolf

d. Kelompok Kartu SKS (Sistem Kredit Semester)

Kartu kelompok ini mendalami Sistem Kredit Semester (SKS) khususnya aspek Akomodasi perbedaan kecepatan belajar, UKBM, Belajar Tuntas, Program remedial dan Pengayaan, Tutorial teman sebagai sebagai peluang PPK, dan semester waktu dan semester kurikulum. Kartu kelompok ini memiliki 9 jenis kartu masing-masing adalah sebagai berikut; (1) Moderator/Narator, (2) Warga Sekolah Akomodasi perbedaan kecepatan belajar, (3) Warga Sekolah UKBM, (4) Warga Sekolah Belajar Tuntas, (5) Program remedial dan Pengayaan, (6) Pelindung Warga Sekolah Tutorial teman sebagai sebagai peluang PPK. (7) Warga Sekolah Semester waktu dan semester kurikulum, (8) Tokoh Spiritual/Seer, (9) Perusuh/ Werewolf, Perusuh/ Werewolf

e. Kelompok kartu Tri Pusat Belajar/Pendidikan Keluarga (Pendikel)

Kartu kelompok ini materi tentang Tri Pusat Belajar/ Tri Centra Pendidikan, Paguyuban kelas Pengasuhan Positif, Kelas Ortu/ Parenting Class, Kelas Inspiratif dan Direktur Mengajar, dan Pentas Kelas Akhir Tahun. Pendidikan keluarga sebagai implementasi Tri Pusat Belajar atau Tri Centra Pendidikan khususnya mendalami materi Kelompok kartu ini memiliki 9 kartu masing-masing adalah sebagai berikut; (1) Moderator/Narator, (2) Pelindung Warga Sekolah Tri Pusat Belajar, (3) Warga Sekolah Paguyuban Kelas , (4) Warga Sekolah Parenting Class, (5) Warga Sekolah Kelas Inspiratif atau Direktur Mengajar, (6) Warga Sekolah Pentas Kelas Akhir Tahun, (7) Tokoh Spiritual/Seer, (8) Perusuh/ Werewolf, (9) Perusuh/ Werewolf. Adapun Isi kartu yang mencerminkan muatan materi dan sosok fisik kartu dipaparkan dalam lampiran. 
Selanjutnya contoh fisik kartu terlampir pada Lampiran 1 dan muatan materi pada kartu Warga Sekolah pada setiap Sub Tema Materi setiap Tema Materi ada pada Lampiran 2.

\section{B. Kelebihan "Werewolf Game in Education" dan pencegahan dampak Werewolf Game}

Pengembangan Werewolf Game menjadi varian Werewolf in Education materi PPK Adiwiyata, Literasi dan SKS pada Tri Pusat Belajar. Varian "Werewolf Game in Education" dimaksudkan untuk memanfaatkan kelebihan Werewolf Game dan meningkatkan peran pembelajaran/pelatihan dan pendidikan serta mengurangi kekurangan atau efek samping sebagai dampak umumnya suatu game.

Tabel. 4.4 Analisis kelebihan dan kekurangan permainan Werewolf in Education

\begin{tabular}{|c|c|c|}
\hline NO & KELEBIHAN/ KEUNTUNGAN & KEKURANGAN \\
\hline 1 & $\begin{array}{l}\text { Dapat digunakan dalam berlatih berfikir } \\
\text { kritis, berkomunikasi, berkolaborasi, } \\
\text { berkreasi dalam strategi bermain peran. }\end{array}$ & $\begin{array}{l}\text { Perlu menyiapkan kartu secara } \\
\text { khusus sesuai dengan muatan materi } \\
\text { yang diinginkan. Sehingga guru } \\
\text { Pembina dituntut menguasai materi } \\
\text { pada kartu }\end{array}$ \\
\hline 2 & $\begin{array}{l}\text { Merangsang pemain menyiapkan diri } \\
\text { mempelajari program-program sekolah } \\
\text { dengan berliterasi saat bermain, bahkan } \\
\text { dapat mempelajari materi permainan } \\
\text { dengan memahami program sekolah. }\end{array}$ & $\begin{array}{l}\text { Guru pembina atau yang } \\
\text { menyiapkan kartu dituntut } \\
\text { menguasai materi yang harus } \\
\text { dituangkan pada kartu }\end{array}$ \\
\hline 3 & $\begin{array}{l}\text { Bersifat menantang, melibatkan } \\
\text { pengendalian emosi dan menarik. }\end{array}$ & \\
\hline 4 & $\begin{array}{l}\text { Karena lebih fokus dalam batasan } \\
\text { materinya, maka jalannya diskusi dalam } \\
\text { bermain peran semakin terarah. }\end{array}$ & \\
\hline 5 & $\begin{array}{l}\text { Kumunitas pemain tidak lagi terbatas } \\
\text { usia, memungkinkan berbagai unsur } \\
\text { pemangku keentingan pada sekolah dapat } \\
\text { ikut bermain. }\end{array}$ & \\
\hline
\end{tabular}

Dari 3 (tiga) kelebihan pada Game Werewolf, saat dimodifikasi menjadi permainan "Werewolf in Education" meningkat menjadi 5 (lima) kelebihan, sehingga mampu menambah 2 (dua) kelebihan baik pada peningkatan kecakapan 4C maupun penguasaan wawasan dan motivasi atas program sekolah khususnya Adiwiyata, Literasi dan SKS maupun Pendidikan Keluarga. Sedangkan kelemaham Werewolf Game dapat ditekan dalam "Werewolf Game in Education" sedikitnya tinggal ada 2 (dua) hal. Meskipun demikian dua kelemahan itu akan memicu peluang keuntungan aspek lainnya karena merangsang tindakan kolaboratif antara guru pembina dengan calon pemain untuk bersama-sama menyiapkan kartunya, saat itu pula dapat digunakan oleh calon pemain memahami matari dan program-program sekolah. 


\section{KESIMPULAN}

Dalam pengembangan kepemimpinan kepala sekolah menyiapkan siswa dengan keterampilan melalui penguatan pendidikan karakter penulis memberikan alternatif berbentuk pemecahan masalan salah satunya melalui tindakan pengembangan diri siswa saat pelaksanaan ekstrakurikuler menggunakan Werewolf in Education yang telah diuji cobakan, diteliti dan dikaji hingga dapat disimpulkan sebgai berikut: Werewolf in Education dengan materi programprogram sekolah dapat memberikan penguatan kecakapan siswa SMA Negeri 2 Blitar Tahun Pelajarn 2017/2018 berupa keterampilan hidup, literasi, dan peningkatan karakter; Werewolf in Education dengan materi Penguatan Pendidikan Karakter (PPK), Adiwiyata, Gerakan Literasi Sekolah (GLS) dan Sistem Kedit Semester (SKS) sebagai media internalisasi program-program sekolah pada siswa secara kekinian (up to date) dan kontekstual (berbasis masalah) mampu menggairahkan kegiatan ekstrakurikuler; dan Werewolf in Education dengan materi Penguatan Pendidikan Karakter (PPK), Adiwiyata, Gerakan Literasi Sekolah (GLS), Sistem Kredit Semester (SKS) dan Pendidikan Keluarga dengan melibatkan guru, orang tua dan pengurus komite sekolah sebagai unsur dari Tri Pusat Belajar mampu menumbuhkan dukungan segenap pemangku kepentingan khususnya siswa, guru (sekolah), orang tua (keluarga), dan pengurus komite sekolah (masyarakat).

\section{SARAN}

Saran bagi siswa dan guru pembina ekstrakurikuler dengan mencermati segenap kelebihan dan manfaat model pembelajaran permainan Werewolf in education perlu terus digunakan sebagai salah satu pilihan dalam pembinaan Ekstrakurikuler dengan harapan mampu memperkuat kecakapan hidup Abad 21 siswa berupa kecakapan 4C, Literasi dan Karakter, meningkatkan pemahaman program sekolah dalam pengembangan Penguatan Pendidikan Karakter, Adiwiyata, Gerakan Literasi Sekolah dan Sistem Kredit Semester (SKS), dan memperkaya wawasan model pembelajaran dalam pembinaan ekstrakurikuler khususnya Werewolf in Education.

\section{DAFTAR RUJUKAN}

Arikunto, Suharsimi. 2006. Prosedur Penelitian Suatu Pendekatan Praktek; Edisi Revisi VI. Jakarta: Rineka Cipta.

Direktorat Pembinaan SMA. 2015. Penguatan Pendidikan Karakter (PPK). Jakarta: Direktorat Pembinaan

Direktorat Pembinaan SMA. 2016. Panduan Penyelenggaraan Gerakan Literasi Sekolah. Jakarta: Direktorat Pembinaan

Direktorat Pembinaan SMA. 2017. Implementasi Kecakapan Abad 21 dalam Pembelajaran di SMA. Jakarta: Direktorat Pembinaan

Direktorat Pembinaan SMA. 2017. Panduan Penyelenggaraan SKS. Jakarta: Direktorat Pembinaan 